\title{
PENGARUH EKSTRAK ETANOL DAUN KEMANGI (Ocimum bacilicum L.) TERHADAP KADAR $\beta 2$ MIKROGLOBULIN, ASAM URAT DAN GAMBARAN HISTOLOGI GINJAL PADA TIKUS PUTIH GALUR WISTAR (Rattus novergicus strain Wistar) YANG DIINDUKSI MONOSODIUM GLUTAMAT
}

\author{
Paramita Septianawati ${ }^{1}$, Hernayanti $^{2}$, Gratiana Ekaningsih W. ${ }^{2}$ \\ ${ }^{1}$ Laboratorium Parasitologi, Fakultas Kedokteran Universitas Muhammadiyah Purwokerto \\ ${ }^{2}$ Laboratorium Genetika dan Molekuler Fakultas Biologi Universitas Jenderal Soedirman \\ Email: mita.prtm2@gmail.com
}

\begin{abstract}
Basil leaves (Ocimum basilicum) is one of the traditional medicinal plants that is used as medicine. This study aims to determine the effect of giving basil leaves on levels of Beta 2 microglobulin, uric acid and kidney histology in white wistar-induced rats in MSG and determine the effective dose of basil leaves in an effort to improve kidney function. This study used 25 male Wistar strain rats with body weight 200-230 g. The test animal group was divided into five groups based on the stage of treatment. The first treatment group was a control group consisting of five mice that were not given basil leaf extract or MSG, the second treatment group was the group that was only given MSG without being given basil leaf extract, the third treatment group was the group given MSG followed by basil leaf extract dose $87,5 \mathrm{mg} / \mathrm{kgBB}$, the fourth treatment group was the group that was given MSG followed by the administration of basil leaf extract with a dose of $175 \mathrm{mg} / \mathrm{kgBW}$, and the fifth treatment group was the group that was given MSG followed by the administration of basil leaf extract at a dose of $350 \mathrm{mg} / \mathrm{kgBB}$. At the end of the treatment, rats were drawn for blood analysis of B2M levels and uric acid levels and kidney tissue uptake, as well as analyzing kidney tissue histology.

The results showed that there were differences between Beta 2 microglobulin, uric acid and kidney histopathology of rats receiving basil leaf extract compared with MSG group without basil leaf extract. This study concludes that consuming basil leaf extract can reduce levels of B2M and uric acid and improve kidney histology induced by MSG.
\end{abstract}

Key Words : Ocimum basilicum, Beta 2 microglobulin, uric acid, renal histology, monosodium glutamate (MSG).

\begin{abstract}
Abstrak
Daun kemangi (Ocimum basilicum) merupakan salah satu tanaman obat tradisional yang dimanfaatkan sebagai obat. Penelitian ini memiliki tujuan untuk mengetahui pengaruh pemberian daun kemangi terhadap kadar Beta 2 mikroglobulin, asam urat dan histologi ginjal pada tikus putih galur wistar yang di induksi MSG dan mengetahui dosis efektif daun kemangi dalam upaya memperbaiki fungsi ginjal. Penelitian ini menggunakan 25 tikus jantan galur Wistar dengan berat badan 200 - 230 g. Kelompok hewan uji dibagi menjadi lima kelompok berdasarkan pada tahap pemberian perlakuan. Kelompok perlakuan pertama adalah kelompok kontrol yang terdiri atas lima ekor tikus yang tanpa diberi ekstrak daun kemangi maupun MSG, kelompok perlakuan kedua adalah kelompok yang hanya diberi MSG tanpa diberi ekstrak daun kemangi, kelompok perlakuan ketiga adalah kelompok diberi MSG dilanjutkan ekstrak daun kemangi dosis $87,5 \mathrm{mg} / \mathrm{kgBB}$, kelompok perlakuan keempat adalah kelompok yang diberi MSG dilanjutkan pemberian ekstrak daun kemangi dosis $175 \mathrm{mg} / \mathrm{kgBB}$, dan kelompok perlakuan kelima adalah kelompok yang diberi MSG dilanjutkan dengan pemberian ekstrak daun kemangi dosis $350 \mathrm{mg} / \mathrm{kgBB}$. Pada akhir perlakuan, tikus diambil darahnya untuk di analisis kadar B2M dan kadar asam urat serta pengambilan jaringan ginjal, serta menganalisis jaringan histologi ginjal. Hasil penelitian menunjukkan bahwa terdapat perbedaan antara Beta 2 mikroglobulin, asam urat dan histopatologi ginjal tikus yang menerima ekstrak daun kemangi dibandingkan dengan kelompok MSG tanpa ekstrak daun kemangi. Studi ini menyimpulkan bahwa mengkonsumsi ekstrak daun kemangi mampu mengurangi kadar B2M dan asam urat serta memperbaiki histologi ginjal yang diinduksi oleh MSG.

Kata kunci : Ocimum basilicum, Beta 2 mikroglobulin, asam urat, histologi ginjal, monosodium glutamat (MSG).
\end{abstract}




\section{Pendahuluan}

Indonesia merupakan negara berkembang yang masih menggunakan bahan alam sebagai obat tradisional, salah satunya adalah kemangi (Ocimum basilicum L). Dalam penelitian Ali, et al menunjukkan adanya nefroprotektif dari pengaruh daun kemangi atau yang disebut basil, telah di ekstrak dosis $100 \mathrm{mg} / \mathrm{kgBB}$ dan $200 \mathrm{mg} / \mathrm{kgBB}$ yang telah diinduksi $\mathrm{AlCl} 3$ yang dilihat dari kadar ureum dan kreatinin. Pada penelitian Sumarni et al ${ }^{2}$ menyatakan bahwa ekstrak kemangi dapat melarutkan batu ginjal kalsium, dimana uji kelarutan menunjukkan bahwa semakin tinggi konsentrasi ekstrak daun kemangi maka semakin besar kelarutannya. Pada penelitian yang dilakukan oleh Mahidin ${ }^{3}$ di dapatkan bahwa pemberian ekstrak daun kemangi dapat memperbaiki sel spermatogenik yang rusak akibat pemberian MSG. Kemangi digunakan untuk terapi dalam mengobati pilek, demam, migrain, diabetes, kram menstruasi, sinusitis, penyakit kardiovaskular, nyeri saraf, gigitan serangga, dan sakit kepala, anti-hiperlipidemia ${ }^{4,5,6}$ Kemangi juga bertindak sebagai antikonvulsan, antiinflamasi, antioksidan, bersifat antiplatelet, antitrombotik, anti-mikroba, hepatoprotektif, imunomodulator dan efek sitotoksisitas, sehingga kemangi memiliki potensi stimulasi yang mengarah pada produksi berbagai obat dari Ocimum di industri farmasi ${ }^{7}$.

Monosodium glutamat (MSG) merupakan salah satu makanan aditif yang banyak digunakan sebagai bahan penyedap rasa dalam perbagai produk makanan. Bahan ini mengandung $78,2 \%$, asam glutamat, $12,2 \%$ natrium dan $9,6 \%$ air ${ }^{8,9}$.

Pemakaian MSG yang berlebih dapat mengakibatkan gangguan kesehatan pada manusia terutama pada ginjal. Konsumsi MSG dalam jangka waktu panjang dapat meningkatkan kalsium fosfat dan berakumulasi di ginjal sehingga dapat menyebabkan penyakit batu ginjal ${ }^{10}$. Kebanyakan di masyarakat kita sering menggunakan MSG ditambahkan pada makanan yang sedang dimasak dalam keadaan panas akan terurai menjadi menjadi 2-Amino-6methyldipyrido[l,2-a:3',2'-d]imidazole (Glu-P-1) dan 2-Aminodipyrido[l,2-a:3',2'-d]imidazole (Glu-P-2), menghasilkan radikal bebas seperti anion superoksida $(\mathrm{O} 2-)^{11}$. Monosodium glutamat juga dapat menghambat penyerapan sistein, yaitu asam amino yang dibutuhkan untuk mensintesis glutation sulf hidril (GSH), sehingga kadar GSH akan mengalami penurunan. Akibat penurunan kadar GSH akan menyebabkan peningkatan radikal bebas terutama dalam bentuk senyawa peroksida, karena GSH merupakan substrat dari enzim Glutation peroksidase (GPx) dan Glutation-S Transferase (GST). Enzim GPx berfungsi untuk mengubah radikal peroksida (H2O2) menjadi $\mathrm{H} 2 \mathrm{O}$ dan $\mathrm{O} 2$, sedangkan GST berfungsi dalam detoksifikasi senyawa toksik ${ }^{12}$.

Peningkatan radikal bebas akan menyebabkan reaksi berantai peroksidasi lipid yang dapat merusak organ terutama ginjal, yang merupakan organ ekskresi. Peristiwa ini menyebabkan kerusakan pada tubulus proksimal ginjal dan penurunan laju filtrasi glomerulus (LFG). Indikator untuk mengetahui adanya kerusakan ginjal terutama pada bagian tubulus proksimalis, dapat dilihat melalui peningkatan kadar $\beta 2$-mikroglobulin (B2M) dalam darah dan urin ${ }^{13}$. Nilai normal B2M dalam plasma sekitar 1-3 mg/l, dan kadarnya akan meningkat dua kali lipat apabila terjadi kerusakan ginjal $^{14,15,16}$.

Beberapa peneliti melaporkan pemakaian MSG dosis tinggi dapat menimbulkan kerusakan pada ginjal. 9. melaporkan tikus yang diberi perlakuan MSG 3 $\mathrm{mg} / \mathrm{g}$ BB menunjukkan perubahan degeneratif dini pada ginjal berupa penyusutan Glomerular / Glomerular shrinkage (GSr) dan hilangnya bagian brush border pada tubulus proksimalis. Tikus yang diberi perlakuan MSG $6 \mathrm{mg} / \mathrm{gBB}$ selama 45 hari menunjukkan perubahan pada korteks interlobular ginjal berupa dilatasi dan kongesti pembuluh darah serta peningkatan degeneratif vaskular pada sel epitel korteks ginjal

MSG yang diberikan pada tikus betina dengan dosis $4 \mathrm{~g} / \mathrm{kgBB}$ selama 180 hari dapat menyebabkan penurunan fungsi ginjal yang ditandai dengan peningkatan asam urat, ureum dan kreatinin ${ }^{17}$. Asam urat merupakan hasil akhir metabolism purin dan berasal dari senyawa xantin. Senyawa xantin akan diubah oleh xantin oksidase menjadi asam urat. Peningkatan radikal bebas O2- akibat paparan MSG akan memicu aktivasi xantin oksidase, sehingga kadar asam urat dalam darah meningkat dan sebagai akibatnya penyakit ginjal akan bertambah parah ${ }^{18}$.

Pengobatan penyakit ginjal atau Acute Kidney Disease (AKD) biasanya menggunakan obat sintetik berupa obat Atrial Natriuretic Peptide (ANP) yang berfungsi untuk melebarkan arteriola aferen dan mengurangi cedera iskemik reperfusi di ginjal. Tetapi pengobatan tersebut dapat menimbulkan efek samping berupa hipotensi ${ }^{19}$. Untuk itu, dicari alternatif pengobatan alami yang efektif tetapi aman bagi ginjal, yang berasal dari tumbuhan seperti kemangi. Kemangi (Ocimum basilicum) merupakan salah satu tanaman yang memiliki kandungan antioksidan pada daunnya 
berupa senyawa flavonoid. Daun O.basilicum yang kaya akan senyawa flavonoid dapat berfungsi sebagai antioksidan serta mampu mencegah dan mengobati penyakit gagal ginjal akut yang diinduksi obat deltametrin. Selain itu, daun kemangi dapat memperbaiki kerusakan ginjal pada tikus yang diinduksi obat cisplatin. Cara kerja flavonoid dalam meredam radikal bebas adalah dengan mendonorkan ion $\mathrm{H}+$ kepada radikal bebas sehingga menjadi netral 20,21

Pada penelitian ini menggunakan daun kemangi (O. basilicum) yang akan diberikan pada tikus yang telah di beri MSG untuk melihat dosis terapi dalam memperbaiki kerusakan ginjal yang dapat dilihat dari kadar Beta 2 mikroglobulin, asam urat dan histologi jaringan ginjal.

\section{Metode}

Penelitian ini dilaksanakan di Laboratorium Research Fakultas Kedokteran Universitas Jenderal Soedirman, Purwokerto pada bulan April hingga Juni 2018. Bahan yang digunakan terdiri dari daun kemangi (Ocimum basilicum L.), MSG, reagen Rat Elisa $\beta 2$ mikroglobulin kit ABIN367427, reagen asam urat BioMajesti JCA-BM6010 DiaSys, dan kemikalia untuk pembuat jaringan histologi ginjal. Alat yang digunakan antara lain timbangan tikus (SF-400), gelas ukur $10 \mathrm{~mL}$, gelas beker $250 \mathrm{~mL}$, labu Erlenmeyer, alat pengaduk, sonde lambung tikus, spuit $5 \mathrm{~mL}$ dan $3 \mathrm{~mL}$ (terumo), tabung EDTA (vaculab), sentrifugator, mikrotip, mikropipet, tabung centrifuge $15 \mathrm{~mL}$, tabung kuvet, spektofotometer Shimadzu 1700, gelas objek dan rak penyimpanan. Penelitian ini menggunakan hewan coba Rattus novergicus jantan galur wistar berusia $2-3$ bulan dan memiliki berat tikus $200-230$ g. Adapun kriteria yang dipilih adalah tikus sehat, artinya tikus dapat bergerak aktif, banyak makan, dan tidak cacat fisik.

Rancangan percobaan menggunakan Rancangan Acak Lengkap (RAL) faktorial dengan lima kelompok. Pada kelompok perlakuan terdapat minimal 5 ekor tikus jantan. Jumlah kelompok perlakuan adalah 5, maka total tikus yang dibutuhkan adalah 25 ekor tikus.

Penelitian ini diawali dengan ekstraksi daun kemangi dengan metode ekstraksi dengan pelarut etanol teknis meliputi beberapa tahapan yaitu preparasi sampel, proses ekstraksi dan proses pemurnian ekstrak dengan rotary evaporator pada suhu $45^{\circ} \mathrm{C}$ dan tekanan $350 \mathrm{mmHg}$. Hasil evaporasi kemudian dianalisa meliputi rendemen, pengujian golongan senyawa aktif yaitu flavonoid.
Selanjutnya, hewan coba dibagi dalam 5 perlakuan. Perlakuan yang diujikan terdiri atas:

$\mathrm{A}=$ kelompok kontrol sehat tikus yang diberikan aquades selama 24 hari secara oral atau kelompok tanpa diberi ekstrak daun kemangi ataupun tanpa MSG.

$\mathrm{B}=$ kelompok kontrol positif atau kelompok tikus yang diberikan larutan MSG dosis $40 \mathrm{mg}$ selama 14 hari. Dilanjutkan dengan pemberian aquades selama 10 hari.

$\mathrm{C}=$ kelompok tikus yang diberikan larutan MSG dosis $40 \mathrm{mg}$ selama 14 hari, setelah itu diberikan ekstrak etanol daun kemangi dengan dosis 87,5 $\mathrm{mg} / \mathrm{kgBB}$ secara peroral selama 10 hari.

$\mathrm{D}=$ kelompok tikus yang diberikan larutan MSG dosis $40 \mathrm{mg}$ selama 14 hari. selama 14 hari, setelah itu diberikan ekstrak etanol daun kemangi dengan dosis $175 \mathrm{mg} / \mathrm{kgBB}$ secara peroral selama 10 hari.

$\mathrm{E}=$ kelompok tikus yang diberikan larutan MSG dosis $40 \mathrm{mg}$ selama 14 hari, setelah itu diberikan ekstrak etanol daun kemangi dengan dosis 350 $\mathrm{mg} / \mathrm{kgBB}$ secara peroral selama 10 hari.

Pada hari ke-26, hewan coba diambil darah dari pleksus vena orbitalis menggunakan pipet kapiler hematokrit pada kelima kelompok perlakuan. Sebelum dilakukan pengambilan darah tikus dipuasakan selama 8 jam terlebih dahulu. Darah diambil sebanyak $3 \mathrm{~mL}$, dimasukan ke dalam tabung vacummed EDTA, kemudian dilakukan sentrifugasi selama 10 menit dengan kecepatan 5000 rpm untuk mendapatkan plasma. Plasma darah yang diperoleh disimpan dalam frezer maksimal 3 bulan pada suhu $-20^{\circ} \mathrm{C}$, sebelum digunakan untuk pemeriksaan parameter kadar B2M dan kadar asam urat ${ }^{22}$.

\section{Pemeriksaan $\boldsymbol{\beta} 2$ mikroglobulin Plasma}

Mempersiapkan semua reagen, larutan standar dan menyiapkan semua reagen, larutan standar, dan sampel yang telah diinkubasi pada suhu kamar (20$25^{\circ} \mathrm{C}$ ). Tahap pertama yang dilakukan adalah membuka wells strip mikroplate dari plate frame. Well A sampai F diberi $100 \quad 1$ standar B2M atau sampel ke masing-masing Wells, dengan kadar $0 \mu \mathrm{g} / \mathrm{ml}, 25$ $\mu \mathrm{g} / \mathrm{ml}, 50 \mu \mathrm{g} / \mathrm{ml}, 100 \mu \mathrm{g} / \mathrm{ml}, 200 \mu \mathrm{g} / \mathrm{ml}, 400 \mu \mathrm{g} / \mathrm{ml}$, dan $800 \mu \mathrm{g} / \mathrm{ml}$ mulai dari konsekuensing. Setelah larutan tersebut masuk ke dalam wells, maka wells ditutup dengan cover diinkubasi selama 60 menit. Setelah diinkubasi, penutup tersebut dibuka dan mikroplate tersebut dicuci dengan wash buffer sebanyak empat kali @ 3001 menggunakan Elisa washer. Tahap selanjutnya, menambahkan pada masing - masing wells tersebut $100 \quad 1$ antibodi beta-2mikroglobulin konjugat dan diinkubasi lagi selama 20 menit yang telah ditutup dengan cover. Setelah selesai 
diinkubasi, penutup tersebut dibuka dan mikroplate tersebut dicuci dengan wash buffer sebanyak empat kali@ 3001 menggunakan Elisa washer. Pada tahap berikutnya, ditambahkan $100 \quad 1$ substrat tetrametil benzidine pada wells, dan terjadi perubahan warna menjadi biru. Selanjutnya, langsung ditambahkan 100

1 Stop Solution $\mathrm{HCl} 0,1 \mathrm{~N}$ pada masing-masing Wells dan terjadi perubahan warna dari biru menjadi kuning. Tahap selanjutnya, absorbansi standar dan sampel dibaca pada Elisa reader dengan panjang gelombang $450 \mathrm{~nm}{ }^{23}$ Dilanjutkan dengan pembuatan kurva kalibrasi standar untuk menetapkan kadar $\beta 2$ mikroglobulin pada sampel.

\section{Pemeriksaan Asam Urat Plasma}

Pemeriksaan asam urat dilakukan dengan cara mempersiapkan alat berupa tabung reaksi. Tabung reaksi tersebut diberi label B (sebagai Blanko), St (sebagai Standar) dan S (sebagai Sampel). Pada tabung tersebut kemudian dipipetkan reagen uric acid sebanyak $1000 \mu 1$. Pada tabung reaksi St ditambahkan dengan $10 \mu 1$ standar asam urat dan pada tabung reaksi $\mathrm{S}$ dipipetkan $10 \mu \mathrm{l}$ plasma, sesuai dengan jumlah sampel yang ada. Tabung-tabung dikocok supaya homogen. Proses berikutnya, seluruh tabung diinkubasi pada suhu kamar selama 20 menit. Setelah itu dilanjutkan dengan pembacaan absorbansi standar dan sampel terhadap blanko pada spektofotometer UV-Vis dengan panjang gelombang $578 \mathrm{~nm}^{24}$.

\section{Pengambilan Organ Ginjal dan Pembuatan Preparat}

Setelah pengambilan darah kemudian dilakukan sacrifice dengan cara diinjeksi ketamin dengan dosis $100 \mathrm{mg} / \mathrm{kgBB}$ secara intraperitoneal, dilanjutkan dengan metode cervical dislocation. Hewan coba dibedah kemudian diambil organ ginjalnya. Ginjal kemudian dipotong menjadi 3 bagian yaitu bagian anterior, median dan posterior, kemudian difiksasi dengan larutan neutral buffered formalin (NBF) selama 1 jam. Ginjal kemudian di dehidrasi menggunakan alkohol bertingkat yang pertama menggunakan alkohol $70 \%$ selama 1 jam, dilanjutkan dengan alkohol $80 \%$ selama 1 jam, dilanjutkan dengan alkohol $90 \%$ selama 1 jam dan kemudian dilanjutkan alkohol 96\% selama 1 jam, setelah itu dilanjutkan dengan alkohol absolut 1 selama 45 menit dan dilanjutkan alkohol absolut 2 selama 45 menit. Dealkoholisasi dalam larutan xylene 1 selama 1 jam, dilanjutkan pemberian xyline 2 selama 1 jam dan dilanjutkan dengan xyline selama 45 menit. Penanaman jaringan dalam blok parafin 1 selama 1 jam dilanjutkan parafin 2 selama 1,5 jam (lampiran 9). Ginjal dalam blok parafin selanjutnya diiris dengan dimensi melintang pada ketebalan $4 \mu \mathrm{m}$ menggunakan mikrotom. Irisan jaringan dilekatkan pada object glass yang telah dilapisi dengan gelatin. Irisan jaringan dideparafinisasi dalam larutan xylene 1 selama 10 menit, xyline 2 selama 10 menit, xyline 3 selama 10 menit. Kemudian diberi alkohol absolut 1 selama 5 menit, alkohol absolut 2 selama 5 menit, dan alkohol 90\% selama 1 menit, alkohol $80 \%$ selama 1 menit, alkohol $70 \%$ selama 1 menit kemudian dianjutkan dengan pemberian akuadest dan ditunggu hingga mengering. Proses pewarnaan menggunakan pewarnaan hematoxylin selama 10 menit kemudian di aliri aquadest dan dilanjutkan pemberian blue buffer selama 10 detik dan setelah itu di aliri dengan air mengalir selama 2 menit dibilas aquadest dan dilanjutkan pewarnaan Eosin selama 2 menit. Jaringan yang telah diwarnai dengan H-E kemudian di mounting atau pengawetan jaringan dan dikeringkan diudara. Evaluasi sediaan histologi dilakukan irisan pada bagian anterior, median, dan posterior. Pada setiap irisan diamati dalam lima lapang pandang yaitu pada bagian kiri dan kanan atas, kiri dan kanan bawah, serta pada bagian tengah ${ }^{25}$.

Aspek yang dievaluasi adalah pada bagian tubulus kontortus proksimal mengalami ada atau tidaknya kerusakan sel berupa iskemik ${ }^{26,27,28}$. Setiap preparat diberikan nama kode organ. Preparat tersebut kemudian diamati dibawah mikroskop dan dicatat hasil yang didapatkan.

\section{Hasil dan Pembahasan}

MSG memiliki dampak negatif terhadap ginjal terlihat dari peningkatan kadar B2M dan kadar asam urat dan persentase kerusakan pada ginjal. Hasil penelitian yang dilakukan oleh Putri, et al (2019) ${ }^{29}$. menunjukkan bahwa pemberian MSG dosis 1,6 $\mathrm{g} / \mathrm{kgBB}$ dapat menyebabkan kenaikan kadar ureum dan kreatinin dalam darah. Dalam penelitian ini pemberian MSG dengan dosis $40 \mathrm{mg}$ mengakibatkan adanya kenaikan kadar B2M dan asam urat dalam darah disertai dengan adanya kerusakan pada histopatologi ginjal. Hal ini dikarenakan MSG mampu mempengaruhi fungsi ginjal dengan cara menurunkan antioksidan dan meningkatkan Reactive Oxygen Species (ROS), sehingga terjadi kerusakan di ginjal.

Kelompok perlakuan yang diberi ekstrak daun kemangi dosis $87,5 \mathrm{mg} / \mathrm{kgBB}, 175 \mathrm{mg} / \mathrm{kgBB}$ dan 350 $\mathrm{mg} / \mathrm{kgBB}$ menunjukkan semakin besar dosis yang diberikan maka semakin menurun kadar asam urat, B2M dan kerusakan jaringan pada ginjal yang telah diinduksi dengan MSG. Hal ini terjadi dikarenakan MSG memiliki kemampuan dalam membentuk radikal bebas yang terikat dalam sel sehingga apabila terjadi konsumsi MSG yang berlebih dapat mengakibatkan 
kerusakan sel terutama di ginjal bagian tubulus proksimal ${ }^{30}$.

Gambar 1. Rerata B2M, asam urat dan jaringan histopatologi ginjal pada tiap kelompok

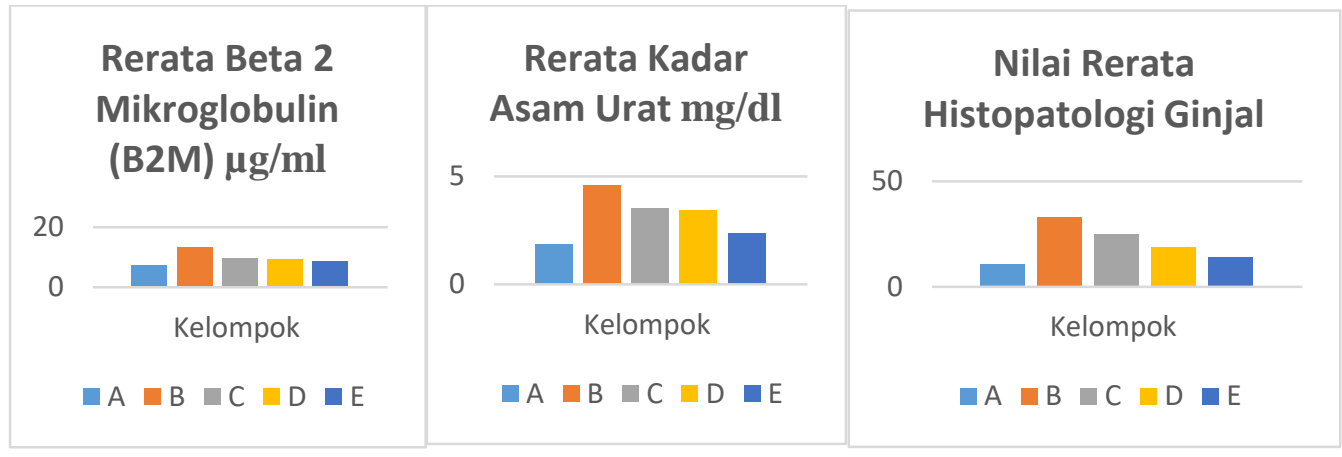

Keterangan : kelompok A : kelompok kontrol, kelompok B : kelompok yang hanya menggunakan MSG, kelompok C : kelompok yang di beri MSG dan ekstrak kemangi 87,5mg/kgBB; kelompok D : kelompok yang diberi MSG dan ekstrak kemangi $175 \mathrm{mg} / \mathrm{kgBB}$, dan kelompok E : kelompok yang diberi MSG dan ekstrak kemangi $350 \mathrm{mg} / \mathrm{kgBB} . \mu \mathrm{g} / \mathrm{ml}=$ mikrogram Per milliliter. $\mathrm{mg} / \mathrm{ml}=$ miligram per mililiter. Histopatologi ginjal dalam persentase $(\%)$. 
Pada penelitian ini kadar B2M dalam darah tikus pada kelompok kontrol adalah $7.32 \mu \mathrm{g} / \mathrm{mL}$ dibandingkan dengan kelompok perlakuan yang lain. Pada penelitian yang dilakukan Eatman et al ${ }^{31}$ kadar B2M pada urin tikus didapatkan sebesar $4 \mu \mathrm{g} / \mathrm{mL}$. Pada individu manusia normal kadar B2M adalah 2,6 $\mathrm{mg} / \mathrm{L}{ }^{14}$ atau ada penelitian Cheung et al 32 menyebutkan rerata kadar atas serum B2M manusia adalah 1,4 $\mu \mathrm{g} / \mathrm{mL}$. Nilai normal B2M di urin individu manusia sebesar 230-300 $\mathrm{g} / \mathrm{l})^{13}$

Pada penelitian ini di dapatkan adanya peningkatan kadar B2M pada tikus yang diinduksi dengan MSG adalah $13.32 \mu \mathrm{g} / \mathrm{mL}$. Pada tikus non diabetik yang diinduksi dengan kontras media di ginjal didapatkan peningkatan kadar B2M 516 ng/mg ${ }^{33}$. Penelitian Shahjahan, et al ${ }^{15}$ menunjukkan bahwa serum $\beta 2$ Mikroglobulin dan kadar kreatinin serum meningkat seiring dengan tingkat keparahan penyakit ginjal pada 88 pasien di Rumah Sakit Sheikh Zayed, Lahore. Pada penelitian Zeng, et al ${ }^{16}$ menyebutkan bahwa adanya peningkatan urin $\beta 2$ microglobulin menunjukkan cedera tubulus proksimal ginjal pada 46 pasien yang menjalani biopsi ginjal. Peningkatan kadar B2M dapat terjadi pada semua pasien gagal ginjal kronis (GGK) dengan rerata 25,6 mg/L, hasilnya menunjukkan adanya peningkatan sampai 10x lipat kadar B2M dibandingkan individu normal.

Beta-2 microglobulin $(\beta 2 \mathrm{M})$ adalah protein non-glikosilasi, dengan berat molekul rendah (11600 Da) dan secara bebas disaring oleh glomeruli. B2M akan diserap kembali oleh tubulus ginjal dan kemudian dihancurkan. Beta 2 mikroglobulin banyak ditemukan pada permukaan limfosit dan sel berinti lainnya. Konsentrasi serum $\beta 2 \mathrm{M}$ sangat bergantung pada kondisi fungsi ginjal karena ginjal adalah tempat utama pembersihan atau clearance. Jumlah serum $\beta 2 \mathrm{M}$ sangat rendah pada individu yang sehat. Kadarnya meningkat pada kasus inflamasi ginjal dan neoplastik 34,35. Pada penelitian ini di dapatkan bahwa hanya kelompok diberi MSG saja terjadi kenaikan B2M yang menandakan adanya cedera ginjal.

Pengukuran B2M merupakan pemeriksaan yang sensitif untuk memeriksa pasien dengan cedera ginjal ${ }^{16}$. Apabila terjadi kerusakan ginjal sebesar 15\%, B2M inilah yang merupakan parameter sensitif mendeteksi kerusakan ginjal. MSG dapat dipecah menjadi glutamat dimana glutamat ini ditangkap oleh reseptor $N$-metil D-aspartat (NMDA) pada ginjal. Apabila
MSG yang terlalu banyak masuk dapat menyebabkan aktivasi NMDA terus menerus sehingga dapat menginduksi perubahan dinamika $\mathrm{Ca} 2+$ seluler sehingga memicu reaksi inducible nitrit oxide synthase (iNos) menyebabkan peningkatan radikal bebas dan peroksidase lipid sehingga terjadi kerusakan sel di tubulus proksimal ginjal 36,37,17. Diketahui bahwa $\beta 2$ microglobulin (B2M) mempunyai ukuran yang kecil, sehingga dapat dengan mudah difiltrasi oleh glomerulus. Sekitar $99 \% \quad \beta 2 \quad$ microglobulin direabsorpsi oleh tubulus proksimal dan dikatabolisme. Pengukuran kadar $\beta 2$ microglobulin serum memberikan informasi gangguan fungsi tubulus. Pada penelitian yang dilakukan oleh Javadi et al ${ }^{38}$ menunjukkan bahwa injeksi intraperitoneal ekstrak etanol $O$. basilicum dapat secara signifikan mengurangi sindrom withdrawal morfin dan skor total withdrawal morfin yang terbagi dalam dua dosis yaitu $20 \mathrm{mg} / \mathrm{kgBB}$ dan $40 \mathrm{mg} / \mathrm{kgBB}$ pada kelompok morfin. Hal ini tampaknya bahwa pemberian ekstrak total etanol $O$. basilicum mungkin menekan aktivasi reseptor NMDA dan mencegah tanda penarikan morfin oleh efek penghambatannya pada sistem kekebalan dan sitokin pro-inflamasi.

Mekanisme kerja ekstrak etanol $O$. basilicum dalam menurunkan kadar B2M yang telah diinduksi MSG adalah dengan cara menekan aktivasi reseptor NMDA sehingga $\beta 2$ microglobulin yang tereabsorpsi oleh tubulus proksimal dan dikatabolisme dapat maksimal. Pada penelitian ini didapatkan informasi bahwa kadar B2M dapat digunakan untuk mendeteksi tingkat kerusakan ginjal dan juga untuk memonitor efek pemberian ekstrak etanol daun kemangi pada tikus yang mengalami cedera ginjal akibat paparan MSG.

Pada penelitian ini yang didapatkan rerata kadar normal asam urat kelompok kontrol sebesar 1,83 $\mathrm{mg} / \mathrm{dL}$ hasil ini hampir sesuai dengan penelitian Ekam, et al $^{39}$, kadar asam urat serum dalam darah tikus kelompok kontrol adalah 1,37 mg/dl. Perbedaan kadar ini dapat disebabkan oleh perbedaan rentang berat badan tikus Wistar albino, pada penelitian Ekam et al 39 sebesar 80-120 g, sedangkan pada penelitian BB tikus adalah 200-230 g. Hal ini dimungkinkan karena adanya perbedaan berat-badan, seperti pada penelitian yang dilakukan oleh Tanaka et al ${ }^{40}$ menyebutkan bahwa obesitas berpengaruh terhadap kenaikan asam urat. Asam urat tinggi memiliki korelasi erat dengan mekanisme fungsi ginjal yaitu obesitas dan kelebihan 
berat badan terkait dengan produksi asam urat berlebihan dan ekskresi asam urat yang buruk. Di antara individu dengan viseral fat accumulation (VFA), penelitian sebelumnya telah menunjukkan bahwa peningkatan kadar asam urat sangat dipengaruhi oleh kelebihan produksi asam urat dengan penurunan ekskresi urat di urin 40, 41.

Pada penelitian ini di dapatkan bahwa MSG dapat memicu kenaikan asam urat, hasil ini sesuai dengan penelitian yang dilakukan 42 yang menunjukkan adanya peningkatan kadar asam urat setelah diberikan MSG secara oral dosis $15 \mathrm{mg} / \mathrm{kgBB}$ pada tikus strain Sprague-Dawely dibandingkan dengan kelompok kontrol. Hal ini menunjukkan bahwa adanya peningkatan kadar asam urat berarti terdapat ketidakmampuan ginjal untuk mengeluarkan produk urat, yang dikaitan dengan peningkatan radikal bebas dalam tubuh ${ }^{43}$. Xanthine oxidase mengkatalisis oksidasi hypoxanthine dari xanthine menjadi asam urat dan menghasilkan anion superoksida yang berlebih sehingga tikus mengalami stres oksidatif ${ }^{17}$. Monosodium glutamat memicu aktivitas xanthine oxidase yang berlebihan sehingga O2- yang dihasilkan semakin banyak.

Penelitian Zaveri et al ${ }^{20}$ menginformasikan bahwa ekstrak daun kemangi dengan dosis 500 $\mathrm{mg} / \mathrm{kgBB}$ yang diberikan lama 10 hari pada tikus dapat menurunkan kadar ureum dan kreatinin. Ekstrak daun kemangi memiliki kemampuan untuk menurunkan kadar asam urat pada manusia, hal ini sesuai dengan penelitian yang dilakukan oleh Ismanto \& Masi ${ }^{44}$ yang menggunakan rebusan air daun kemangi dapat menurunkan asam urat dalam darah. Pada penelitian yang dilakukan oleh El-Nahl et al ${ }^{45}$, didapatkan bahwa pemberian ekstrak etanol daun kemangi dosis $0,70 \mathrm{~g} / \mathrm{KgBB}$ tikus dan $0,35 \mathrm{~g} / \mathrm{KgBB}$ tikus dapat menurunkan asam urat pada tikus yang hiperkolesterolemia. Daun kemangi mengandung senyawa flavonoid yang dapat menghambat terbentuknya asam urat dalam tubuh. Flavonoid dapat mendonorkan $\mathrm{H}+$ terhadap $\mathrm{O} 2$ - sehingga menjadi netral. Adapun senyawa flavonoid yang terkandung dalam kemangi antara lain luteolin, quercetin, sapogenin dan kaemferol; yang berpotensi menghambat aktivitas xanthine oksidase sehingga dapat menghambat pembentukan asam urat ${ }^{46}$. Pada penelitian ini menunjukkan bahwa ekstrak daun kemangi dapat berpotensi dalam menurunkan kadar asam urat yang diinduksi oleh MSG.
Respon fisiologis yang tercermin dari kadar B2M dan asam urat belum secara signifikan berdampak pada struktur ginjal. Hasil pengamatan histologi pada penelitian ini menunjukkan pada tikus yang diinduksi MSG lebih banyak mengalami kerusakan pada ginjal yang ditandai dengan iskemik pada tubulus proksimal ginjal. Menurut Khalid, et al ${ }^{47}$ adapun tingkatan sistem skoring kerusakan iskemik ginjal pada tubulus ginjal adalah nilai 0 apabila tidak didapatkan kerusakan, nilai 1 didapatkan adanya kerusakan pada Brush border (BB) kurang dari 25\% dari sel tubulus dan masih terdapat integritas membran basal, nilai 2 apabila terjadi kerusakan BB lebih dari $25 \%$ pada sel tubulus dan penebalan membran basalis, nilai 3 apabila terjadi kerusakan BB lebih dari $25 \%$ pada sel tubulus dan penebalan membran basalis ditambah dengan inflamasi, terdapat cast formation dan nekrosis sel tubulus 60\%; dan nilai 4 apabila terjadi kerusakan BB lebih dari $25 \%$ pada sel tubulus dan penebalan membran basalis serta nekrosis sel tubulus lebih dari $60 \%$.

MSG dapat menginduksi kerusakan ginjal disebabkan oleh radikal bebas berlebih yang masuk ke dalam tubulus ginjal ${ }^{12}$. Antioksidan adalah zat apa pun yang ketika hadir pada konsentrasi rendah secara signifikan menunda atau mencegah oksidasi sel seperti protein, lipid, karbohidrat dan DNA ${ }^{48}$. Investigasi ini mengungkapkan bahwa pemberian oral MSG menekan aktivitas tersebut dari katalase (CAT), glutathione (GSH) dan superoksida dismutase (SOD) dalam hati dan ginjal. Sehingga akan terjadi peningkatan aktivitas lipid peroksidasi (LPO) di hati dan jaringan ginjal pada zat aditif atau MSG ${ }^{49,50}$. Peroksidasi lipid juga dapat meningkat karena peningkatan glutamat darah dan glutamin yang dilaporkan mendukung lipogenesis ${ }^{51}$. Pada hati, degradasi glutamin menghasilkan glutamat yang kemudian mengalami deaminasi oksidatif untuk menghasilkan ion amonium, $\alpha$-ketoglutarat dan NADH. Oleh karena itu, peningkatan kadar glutamin juga dapat memulai peroksidasi lipid dengan mengubah potensi redoks sel ${ }^{52}$. Oleh karena itu, antioksidan alami dapat berperan sebagai pemulung radikal bebas pada MSG yang menginduksi cedera ginjal.

Penelitian Sakr \& Al-Amoudi ${ }^{21}$ menunjukkan bahwa peroksidasi lipid dapat dihambat dan aktivitas enzim SOD dan CAT meningkat setelah pengobatan dengan O.basilicum, menunjukkan peran ekstrak O.basilicum dalam memadamkan pembentukan ROS. 
Daun O.basilicum adalah sumber flavonoid yang kaya yang telah terbukti memiliki berbagai sifat biologis yang berkaitan dengan mekanisme antioksidan. Zhang et al., (2009) melaporkan bahwa komponen utama O. basilicum adalah: linalool $(29,68 \%)$, (Z) ester metil asam sinamat $(21,49 \%)$, cyclohexene $(4,41 \%)$, alfacadinol $(3,99 \%) \quad, \quad 2,4$-diisopropenyl-1-metilvinylcyclohexane $(2,27 \%)$, asam 3,5-piridindikarboksilat, 2,6dimetil-dietil ester $(2,01 \%)$, betacubebene $(1,97 \%)$, guaia1 (10), 11-diena (1,58\%), kadinena $(1,41 \%)$, (E) -metil ester asam kumur $(1,36 \%)$ dan beta-guaiene $(1,30 \%)$. Disimpulkan dari penelitian Sakr \& Al-Amoudi ${ }^{21}$ bahwa efek perbaikan O. basilicum terhadap toksisitas deltamethrin ginjal dapat dikaitkan dengan aktivitas antioksidan dari satu atau lebih flavonoidnya.

Oforofuo et al., ${ }^{53}$ menunjukkan bahwa tingkat perkembangan nekrosis seluler ginjal tergantung pada tingkat keparahan toksisitas MSG yang ditentukan oleh dosis dan durasi paparan. Pada penelitian Singh ${ }^{9}$ menggunakan MSG dosis $6 \mathrm{mg} / \mathrm{gBB}$ selama 45 hari pada tikus Wistar dewasa menunjukkan adanya nekrosis pada tubulus, terdapat sel-sel inflamasi (neutrofil, eosinofil dan limfosit) pada tubulus ginjal dan hemoragik fokal di antara tubulus ginjal. Menurut Kuldip \& Ahluwalia ${ }^{54}$ terjadinya nekrosis pada ginjal disebabkan paparan MSG dosis $8 \mathrm{mg} / \mathrm{gBB}$ pada mencit jantan meningkatkan pembentukan radikal bebas yang memicu terjadinya reaksi berantai peroksidase lipid yang merusak ginjal. Keberadaan radikal bebas ditunjukkan dengan adanya peningkatan malondialdhyde (MDA) yang merupakan produk akhir dari peroksidasi lipid. Radikal bebas juga menyebabkan stres oksidatif yang ditunjukkan dengan penurunan kadar superoxidase dismutase (SOD), katalase dan GPx pada jaringan ginjal. Penelitian ini berbeda dengan penelitian yang dilakukan oleh Candra et al, ${ }^{30}$ yang mendapatkan hasil kelompok kontrol positif yaitu tikus $R$. novergicus yang diberi MSG 5 $\mathrm{mg} / \mathrm{gBB}$ tikus/hari selama 28 hari terdapat perbedaan yang bermakna antara rerata jumlah tubulus proksimal yang rusak dibanding kelompok kontrol negatif. Vinodini ${ }^{52}$ menggunakan dosis MSG lebih rendah dibandingkan dosis MSG pada penelitian ini yaitu 5 $\mathrm{mg} / \mathrm{kgBB}$ selama 28 hari ternyata telah menimbulkan kerusakan pada ginjal.

Pada penelitian ini didapatkan juga bahwa iskemik pada tubulus ginjal pada kelompok yang diberi ekstrak daun kemangi lebih sedikit dibanding dengan yang diberi hanya MSG saja.

Hal ini menunjukkan bahwa ekstrak daun kemangi dapat mencegah kerusakan ginjal, hal ini sesuai dengan penelitian Samie \& Ahmed ${ }^{55}$ yang menyebutkan bahwa pemberian ekstrak daun kemangi dapat memperbaiki kelainan histologi ginjal pada tikus yang telah di induksi dengan adriamicyn (obat kemoterapi). Kerusakan tubulus ginjal akibat paparan MSG berupa penyempitan lumen tubulus akibat pembengkakan tubulus ginjal dan pada lumen tubulus dijumpai silinder hialin yang merupakan kumpulan sisa-sisa protein yang rusak serta nekrosis pada bagian epitel tubulus ginjal ${ }^{30}$.

Pada penelitian Zaveri ${ }^{20}$ yang menginduksi dua kelompok tikus dengan cisplatin (obat kemoterapi) 5 $\mathrm{mg} / \mathrm{kgBB}$ selama 5 hari, kemudian kelompok pertama diberi ekstrak etanol daun kemangi $O$. basilicum pada dosis 300 dan kelompok kedua diberi ekstrak etanol $500 \mathrm{mg} / \mathrm{kgBB}$ selama 10 hari. Parameter yang diamati adalah perbedaan kadar ureum, kreatinin dan histopatologi ginjal. Pemberian ekstrak etanol daun kemangi pada kedua kelompok tikus dapat menurunkan kadar ureum, kreatinin dan memperbaiki gambaran histopatologis ginjal yang rusak.

MSG menjadi penambah rasa yang paling populer di seluruh dunia. Ada banyak fakta kontroversial tentang efek buruknya, sehingga timbul keraguan tentang keamanan penggunaan MSG dalam jangka panjang. Banyak penelitian untuk menyelidiki efek toksiknya pada organ yang berbeda terutama yang memainkan peran penting untuk metabolisme atau ekskresinya seperti ginjal. Hasil penelitian ini menunjukkan bahwa pemberian MSG dengan dosis 40 $\mathrm{mg}$ /hari selama 14 hari pada kelompok perlakuan memberikan pengaruh terhadap kadar B2M, asam urat dan struktur ginjal tikus setelah diberi ekstrak etanol daun kemangi selama 10 hari dengan dosis berbeda (87,5 mg/kgBB; $175 \mathrm{mg} / \mathrm{kgBB}$ dan $350 \mathrm{mg} / \mathrm{kgBB}$ ) menunjukkan penurunan kadar asam urat dan B2M yang semula tinggi di dalam darah, dan menunjukkan adanya perbaikan cedera ginjal akut dalam histopatologi ginjal.

Penelitian Candra et al ${ }^{30}$ menyatakan bahwa pajanan MSG dapat menyebabkan kerusakan tubulus proksimal dan korpuskulum ginjal serta terjadi regenerasi setelah 14 hari penghentian pajanan MSG. Pada penelitian ini kelompok kontrol positif hanya 
diberi dengan MSG saja selama 14 hari dan pada hari ke-10 paparan MSG dihentikan, parameter yang diamati adalah jumlah iskemik ginjal pada tikus kelompok yang diberi dengan ekstrak daun kemangi dan dibandingkan dengan tikus sehat. Monosodium glutamat bersifat nefrotoksik yang menyebabkan peningkatan ROS intraseluler dan terjadi hipoksia pada sel sehingga sel pada tubulus proksimal ginjal menjadi mengecil, karena sintesis protein menurun, terjadi degradasi protein dalam sel, serta meningkatnya kerusakan organel sel sehingga terjadi iskemik dan dapat berlanjut menjadi nekrosis atau kematian sel 56 , 57,26 Kerusakan jaringan tubulus ginjal dapat digambarkan dengan hilangnya brush border, ditemukannya intratubular cast, degenerasi vakuola dan nekrosis pada tubulus proksimal ginjal tikus. Pada penelitian Sari ${ }^{58}$ didapatkan kerusakan epitel tubulus proksimal ginjal, pembengkakan tubulus dengan sitoplasma granuler yang terjadi karena pergeseran air ekstraseluler ke dalam sel. Pergeseran cairan ini terjadi karena adanya zat toksik yang menyebabkan perubahan muatan listrik pada permukaan sel epitel tubulus, perubahan transpor aktif ion dan asam organik, dan kemampuan akumulasi ginjal dan akhirnya mengakibatkan tubulus rusak, aliran menurun. Gambaran pembengkakan sel disebut degenerasi albuminosa atau degenerasi parenkimatosa atau cloudy swelling (bengkak keruh). Degenerasi ini merupakan bentuk degenerasi yang paling ringan serta bersifat reversibel. Hal inilah yang mungkin menyebabkan perbedaan jumlah sel yang mengalami degenerasi sel lumen tubulus proksimal pada kelompok dipapar MSG saja dibandingkan dengan kelompok yang diberi dengan ekstrak etanol daun kemangi setelah pemberian MSG. Pemberian O.basilicum meningkatkan perubahan histopatologis yang diinduksi dalam ginjal oleh MSG dapat dilihat kemampuan ekstrak etanol daun kemangi dalam menurunkan peroksidase lipid dan meningkatkan enzim atioksidan, karena O.basilicum mengandung tingginya sumber flavonoid. Perbedaan rerata kenaikan tertinggi kadar B2M dan asam urat, serta kerusakan jaringan histopatologi ginjal tampak pada kelompok B yang merupakan kelompok yang hanya diberi MSG saja. Pada kelompok C, D, dan E merupakan kelompok yang diberi MSG dan diberikan ekstrak etanol daun kemangi dosis 87,5 mg/kgBB; 175 $\mathrm{mg} / \mathrm{kgBB}$ dan $350 \mathrm{mg} / \mathrm{kgBB}$ menunjukkan adanya penurunan kadar B2M, asam urat, dan perbaikan jaringan histopatologi ginjal, yang artinya semakin besar pemberian ekstrak etanol daun kemangi akan memiliki dampak dalam perbaikan fungsi ginjal yang hampir sama dengan nilai kadar B2M dan asam urat serta keadaan jaringan histologi ginjal yang capaian nilainya hampir mendekati nilai normal pada kelompok kontrol.

\section{Simpulan}

Hasil penelitian menunjukkan bahwa pemberian Ocimum basilicum mampu mengalami perbaikan kerusakan fungsi ginjal yang ditimbulkan akibat pemberian MSG yang dibuktikan dengan penurunan kadar B2M, asam urat dan tingkat kerusakan ginjal.

\section{Ucapan Terima Kasih}

Penulis menyampaikan terima kasih kepada Prof. Dr.rer.nat. Imam Widhiono M. Z, M.S. selaku Dekan Fakultas Biologi Universitas Jenderal Soedirman; Dr. Bambang Heru Budianto, M.S. selaku Koordinator Program Studi S2 Ilmu Biologi Fakultas Biologi Universitas Jenderal Soedirman; Dr. Hernayanti selaku dosen pembimbing I dan Dra. Gratiana Ekaningsih Wijayanti, M. Rep. Sc, Ph.D selaku dosen pembimbing II sekaligus dosen Pembimbing Akademik yang telah memberikan pengarahan dan bimbingan selama penelitian dan penyusunan tesis.

\section{Daftar Referensi}

1. Ali, A.; Qasim, M.; Aftab, MN; Azam, SM; Iqbal, F; Akram, S and Hussain MZ. 2017. Effects of Ocimum basilicum extract on hematological and serum profile of male albino mice after $\mathrm{AlCl} 3$ induced toxicity. Pure and Applied Biology. doi:10.19045/bspab.2017.60050

2. Sumarni, Wiwin; Sabang, Sri Mulyani; dan Ratman. 2017. Effect of Basil (Ocimum sanctum L.) Leaves Extracts toward Solubility of Kidney Stones Calcium. J. Akad Kim 6 (3) : 187-190.

3. Mahidin, Maulana dan Susiyadi. 2018. Pengaruh Pemberian Ekstrak Etanol Daun Kemangi (Ocimum basilicum L.) Terhadap Jumlah Sel Spermatogenik Tikus Putih (Rattus novergicus) Galur Wistar Jantan yang Di Induksi Monosodium Glutamat. Journal Herb of Medicine 1 (1) : 19-30.

4. Ozcan M, Chalchat JC. Essential oil of Ocimum basilicum L. and Ocimum minimum L, in turkey. Journal of Food Science. 2005; 20: 223-8.

5. Sethuraman J, Nehru $\mathrm{H}$, Shanmugam K, Balakrishnanan P. Evaluation of potent 
phytochemicals and antidiabetic activity of Ficus racemose L. World Journal of Pharmaceutical Research. 2017; 6(15): 909-20.

6. Ramalingam PS, Sagayaraj M, Ravichandiran P, Balakrishnanan P, Nagarasan S, Shanmugam K. Lipid peroxidation and anti-obesity activity of Nigella sativa seeds. World Journal of Pharmaceutical Research. 2017; 6 (10): 882-92.

7. Purushothaman, B; PrasannaSrinivasi, R.; Suganthi, P., Ranganathan, B., Gimbun, J. dan Shanmugam, K. 2018. A Comprehensive Review on Ocimum basilicum. Journal of Natural Remedies 18 (3) : 71-86.

8. Samuel, A. 1999. The toxicity/safety of (MSG): a study in suppression of information. Accountability Research, 6(4): 259-310.

9. Singh, BR, Gajbe, U., Reddy, AK., dan Kumbhare, V. 2014. Histological Changes In Kidneys Of Adult Rats Treated With Monosodium Glutamate: A Light Microscopic Study. International Journal of Medical Research dan Health Sciences 4 (1) : 1-6.

10. Sharma, A; Wongkham, C; Prasongwattana, V; Piyanard, Boonnate; Thanan, R; Reungjui, S; and Cha'on, ubon. 2014. Proteomic analysis of kidney in rats chronically exposed to monosodium glutamate. PLoS One 9(12) : 1-11.

11. Manabe, S.; Yanagisawa, H.; Ishikawa, S.; Kitagawa, Y.; Kanai, Y.; and Wada, O. 1987. Accumulation of 2-Amino-6-methyldipyrido[1,2a:3',2'-d]imidazole and 2-Aminodipyrido[1,2a:3',2'-d]imidazole, Carcinogenic Glutamic Acid Pyrolysis Products, in Plasma of Patients with Uremia. CANCER RESEARCH, 47: 6150-6155.

12. Huy, LA.; He, H. dan Huy, C. 2008. Free Radicals, Antioxidants in Disease dan Health. InternatIonal journal of BIomedIcal Science, 4(2) : 89-97.

13. Argyropoulos, Chistos; Chen, Shan Shan; Ng, Yue-Harn; Roumelioti, Maria-Eleni; SHaffi, Kamran; Singh, Pooja dan Tzamaloukas, Antonios. 2017. Rediscovering Beta-2 Microglobulin As a Biomarker across the Spectrum of Kidney Diseases. Frontiers in Medicine 4 (73) : 1- 25.

14. Jeloka, T., Mathur, MD., Kaur, K., Kohli, R., Sighn, NP dan Rizvi. 2001. Beta 2 Microglobulin in Chronic Renal Failure Dan Effect of Different Dialyzer Membrane on Its Clearance. Indian Journal of Nephrology, $11: 160-164$.
15. Shahjahan, RY.; Muhammad, AJM.; Mahnoor, K.; Jawaid, S.; dan Javaid Hussain. 2011. Correlation Of Beta 2 Microglobulin With Serum Creatinine Dan Creatinine Clearance In Patients With Different Levels Of Renal Function. Gomal Journal of Medical Sciences 9 (2) : 178 - 183.

16. Zeng, X; Hossain, D; Bostwick, DG; Herrera, GA; Ballester, B and Zhang, PL. 2014. Urinary $\beta 2-$ Microglobulin is a Sensitive Indicator for Renal Tubular Injury. SAJ Case Report 1(8) : 1-6.

17. Paul, MVS; Abhilash, M.; Varghese, MV; Alex, Manju dan Nair, R. Harikumaran. 2012. Protective effects of $\alpha$-tocopherol against oxidative stress related to nephrotoxicity by monosodium glutamate in rats. Toxicology Mechanisms dan Methods, 22(8): 625-630

18. Giordano, C.; Karasik, O.; King-Morris, K., dan Asmar, A. 2015. Uric Acid as a Marker of Kidney Disease: Review of the Current Literature. Hindawi Publishing Corporation Disease Markers, $2015: 382918$, pmid : 26106252.

19. Jo, SK.; Rosner, MH. dan Okusa, MD. 2007. Pharmacologic Treatment of Acute Kidney Injury: Why Drugs Haven't Worked and What Is on the Horizon. Clin J Am Soc Nephrol, 2: 356-365

20. Zaveri, M., Desai, N. and Movaliya, V. 2011. Effect of Ocimum basilicum on Cisplatin Models of Acute Renal Failure. Advance Research in Pharmaceuticals and Biologicals ARPB 1 (2) : 91102.

21. Sakr, SA. dan Al-Amoudi, WM. 2012. Effect of leave extract of Ocimum basilicum on deltamethrin induced nephrotoxicity dan oxidative stress in albino rats. Journal of Applied Pharmaceutical Science 02 (05) : 22-27

22. Cuhadar S., Koseoglu M., Atay A., Dirican A. 2013. The effect of storage Time and freeze thaw cycles on the stability of serum sampel. Biochem Med (Zagreb) 23 (1) : 70-77.

23. Bioassay Technology Laboratories. 2014. Rat $\beta 2$ mikroglobulin Elisa Kit. Penerbit Jungjiang International Building 218 Ninggou Rd YangPu Dist. Shanghai, China. 14 halaman.

24. Marshall, WJ. 2012. Uric Acid. Association for Clinical Biochemistry : 1-5.

25. Zulfiani; Ilyas, S.; dan Hutahanean, S. 2013. Pengaruh Pemberian Vitamin C dan E Terhadap Gambaran Histologis Ginjal Mencit (Mus musculus L.) yang Dipajankan Monosodium Glutamat (MSG). Jurnal USU 1 (3): 1-6. 
26. Mitchell dan Cotran. 2007. Buku Ajar Patologi Robbins Volume 1. Edisi VII. Jakarta: EGC.

27. Colvin, RB., Chang, A.; Farris, AB; Kambham, N.; Cornell, LD.; Meehan, SM.; Liapis, H.; Gaut, J.; Bonsib, SM.; Seshan, SV.; Vasilyev, A. and Jain, S. 2011. Diagonstic Pathology : Kidney Disease, First Edition. Boston : Amirsys Publishing, Inc, 3144 page.

28. Peres, LC.; Seturaman, C.; Al-Adnani, M.; and Cohen, MC. 2012. Necrotic epithelial cells in proximal renal tubules of 2 nd trimester fetuses: is this "acute tubular necrosis"?. Int J Clin Exp Pathol; 5(4):326-330.

29. Putri, GSS; Romdhoni, MF, dan Bahar, Y. 2019. Pengaruh Ekstrak Etanol Daun Kemangi (Ocimum basilicum) Terhadap Kadar Ureum dan Kreatinin Tikus Galus Wistar Jantan (Rattus norvegicus strain Wistar) yang Diinduksi Monosodium Glutamate (MSG). Herb Medicine Journal (HMJ) 2 (1) : 36-43.

30. Chandra, Aulia; Trianto, Heru Fajar; dan Ilmiawan, M. In'am. 2015. Gambaran Histologis Korteks Ginjal Tikus (Rattus norvegicus) Pasca Penghentian Pajanan Monosudium Glutamat per Oral. Jurnal Cerebellum, 1 (3) : 202-221.

31. Eatman, D., Elhassey, M., Okirie, V., Emmett, N., and Bayorh, M. 2016. Urinary expression of beta2 microglobulin and osteopontin increases in saltinduced hypertensive rats. Journal of the American Society of Hypertension 10(4S) : e56-e73.

32. Cheung, BMY; Tam, FCC; Cheung, CL; Chan, EYT; Tsui, SH and Lee, SWL. 2016. Beta-2 microglobulin level in serum is elevated in patients presenting with acute coronary syndrome. Journal Of the American College of Cardiology 68 (16) : C97.

33. Rouse, RL; Stewart, SR; Thompson, KL and Zhang, J. 2013. Kidney Injury Biomarkers in Hypertensive, Diabetic, and Nephropathy Rat Models Treated with Contrast Media. Journal Toxicology Pathology 41 : 662-680.

34. Javadi, S.; Rezaei, SA.; Allahverdizadeh, M. 2014. Interrelationship of ßeta-2 microglobulin, blood urea nitrogen and creatininstreptozotocin-induced diabetes mellitus in rabbits. Veterany Research Forum 5 (1) : 7-11.

35. Naji, NA; Khorsheed, SH; and Mustafa, IF. 2016. Study the activity of Tryptase And Beta 2Microglobulin Levels In the Sera of Patients With Chronic Renal Failure And Rheumatoid Arthritis.
Kirkuk University Journal /Scientific Studies (KUJSS) 11 (1) : p.p(138-154)

36. Sharma, A. 2015. Monosodium glutamate-induced oxidative kidney damage dan possible mechanisms : a mini-review. Journal Of Biomedical Science, 22 (93) : 1-6.

37. Gill, S. dan Pulido, O. 2005. Glutamate Receptors in Peripheral Tissue, Excitatory Transmission Outside the CNS. Canada : Toxicology Research, 275 page.

38. Javadi, Mitra; Parvizpur, Alireza; Hamedeyazdan, Sanaz; Charkhpour, Mohammad; and Fathi-azad, Fatemeh. 2017. Evaluation the effect of Chronic Administration of Ethanolic Extract of Ocimum basilicum on Morphine Withdrawal Syndrome in Rat. Iranian Journal of Pharmaceuticl Sciences 13 (1) : 59-63.

39. Ekam, VS; Johson, JT; Oka, VO; Archibong, AN, and Odey, MO. 2012. Uric acid, urea and bilirubin levels of albino rats treated with activity directed fractions of Vernonia Amygdalina during acetaminophen induced hepatotoxicity. Annals of Biological Research, 3 (12):5595-5599

40. Tanaka, Kentaro; Ogata, Soshiro; Tanaka, Haruka; Omura, Kayoko; Honda, Chika; and Hayakawa, Kazuo. 2015. The relationship between body mass index and uric acid: a Study on Japanese adult twins. Environ Health Prev Med 15 (20) : 347-353

41. Matsuura, F; Yamashita, S; Nakamura, T; Nishida, M; Nozaki, S; Funahashi, T and Matsuzawa, Y. 1998. Effect of visceral fat accumulation on uric acid metabolism in male obese subjects: visceral fat obesity is linked more closely to overproduction of uric acid than subcutaneous fat obesity. Journal PubMed 47 (8) : 929-933.

42. Ahmed, Mona HM. 2016. Effect of some Food Additives Consumption on the Body Weight and Toxicity and the Possible Ameliorative Role of Green Tea Extract. Middle East Journal of Applied Sciences, 06 (04) : 716-730.

43. Jin, M., F. Yang, I. Yang, Y. Yin, J.J. Luo, H. Wang and X.F. Yang, 2012. Uric acid, hyperuricemia and vascular diseases. Front Biosci., 17: 656-669.

44. Ismanto, AY dan Masi, G. (2016). Pengaruh Air Rebusan Daun Kemangi Terhadap Kadar Asam Urat Darah Pada Penderita Hiperurisemia di Wilayah Kerja Puskesmas Wolang. e-Journal Keperawatan 4 (1) : $1-7$. 
45. El-Nahl, DM.; THabet, HA., and Ahmed, S. 2012. Study the impact of sweet basil extracts (Ocimum basilicum) to reduce blood cholesterol. Egypt. J. of Nutrition and Health, 7 (1) : 51-68.

46. Cos, P.; Ying, L; Calomme, M; Hu, JP; Cimanga, $\mathrm{K}$; Poel, Van J; Vlietinck, AJ; and Berohe, V. 1998.Structure Activity Relationship and Classification of Flavonoids as Inhibitors of Xanthine Oxidase and Superoxide Scavengers. Journal of Natural Products, 61 (1), 71-76.

47. Khalid, Usman; Pino-Chavez, Gilda; Nesargikar, Prabhu; Jenkins, Robert H; Bowen, Timothy; Fraser, Donald J.; dan Chavez, Rafael. 2016. Kidney ischaemia reperfusion injury (IRI) in the rat: the EGTI scoring system as a valid and reliable tool for histological assessment. Journal of Histology and Histopatology, 3 (1) : 1-7. ISSN 2055-091x, doi: 10.7243/2055-091X-3-1.

48. Irshad M, and Chaudhuri PS. 2002. Oxidantantioxidant system Role and significance in human body. Indian J. EXP. Biol., 40, 1233-1239.

49. Voja P, Dusica P, Gordana K, Dusan S, Tatjana JS, Snezana C, and Dragana V, Effect of monosodium glutamate on oxidative stress and apoptosis in erat thymus, Mol Cell Biochem. 2007, 303, 161-166.

50. Hassan, HA and Yousef MI. 2010. Ameliorating effect on chicory (Cichorium intybus L.)supplemented diet against nitrosamine precursorsinduced liver injury and oxidative stress in male rats Food Chem. Toxicol. 48 (8-9), 2163-2169.

51. Malik VBT, and Ahluwalia P. 1994. Studies on effect of monosodium gllutamate (MSG) on various fractions of lipids and certain carbohydrate metabolic enzymes in liver and blood of adult mice. Toxicol. Lett. 74, 6977.

52. Vinodini, NA; Nayanatara, AK; and Ramaswamy, C. 2010. Study on evaluation of monosodium glutamate induced oxidative damge on renal tissue on adult Wistar rats. J. Chin. Clin. Med., 5(3): 144-147.

53. Oforofuo, IAO, Onakewhor, JUE and Idaewor, PE. 1997. The effect of Chronic Admin of MSG on the histology of the Adult Wistar rat Testes. Bioscience Research Communications. Vol. 9, No. $2,: 30-56$.

54. Kuldip, S and Ahluwalia, P. 2005. Alteration in some antioxidants enzymes in cardiac tissue upon monosodium glutamate administration to adult male mice. Indian Journal of Clinical Biochemistry, 20(1): 43-46.

55. Samie, HAA dan Ahmed, RA. (2017). Effect of Aqueous Extract of Basil (Ocimum basilicum) Leaves on Nephrotoxicity Induced Bay Adriamycin in Male Rats : Histological and Immunohistochemical Assessment. International Journal of Applied and Pure Science and Agriculture 3 (3) : $99-110$.

56. Bruckner JV, Alan D. 2001. Toxic effects of solvents and vapors. Chapter 24. In: Klassen D, editor. Cassarett \& Doull's Toxicology: The basic science of poisons. 6th edition. New York: Mc Graw Hill; page 590.

57. Mescher, AL. 2016. Junquira's Basic Histology Text and Atlas, Fourteenth Edition. United State : Mc Graw Hill Education.

58. Sari, Yeti Eka Sispita. 2018. Gambaran Histologi Ginjal Tikus Wistar Yang Terpapar MSG Setelah Perlakuan Diberikan Jus Tomat Dan Diberhentikan Perlakuan Saja. The Journal of Muhammadiyah Medical Laboratory Technologist, 1 (2) : 62-69.

59. Barnes JL, and Gorin Y (2011) Myofibroblast differentiation during fibrosis: role of $\mathrm{NAD}(\mathrm{P}) \mathrm{H}$ oxidases. Kidney Int 79: 944-956. doi:10.1038/ki. 2010.516. PubMed: 21307839.

60. Bilal, A.; Jahan, N.; Ahmed, A.; Bilal, SN.; Habib, S.; dan Hajwa, S. 2012. Phytochemical dan Pharmacological Studies on Ocimum basilicum Linn-A Review. IJCRR, International Journal of Current Reseach Review 4 (23), 73-83.

61. Contini, MC.; Millen, N.; Riera, N. and Mahieu, S. 2012. Kidney and Liver Functions and Stress Oxidative Markers of Monosodium GlutamateInduced Obese Rats. Food and Public Health, 2 (5) : $168-177$.

62. Dahlan, S., 2014. Statistika Untuk Kedokteran dan Kesehatan Edisi 5. Jakarta: Salemba Medika.

63. Daniel, VN.; Daniang, IE.; dan Nimyel, NI. 2011. Phytochemical Analysis dan Mineral Elements Composition of Ocimum Basilicum Obtained in JOS Metropolis, Plateau State, Nigeria. International Journal of Engineering \& Technology IJET-IJENS 11 (06) : 135 - 138.

64. El-Azim, MHM.; Abdelgawad, AAM.; El-Gerby, M.; Ali, S. and El-Mesallamy, A. 2015. Phenolic Compounds dan Cytotoxic Activities of Methanol Extract of Basil (Ocimum basilicum L.), Microbial \& Biochemical Technology, 7(4), 182-186. 
65. Ervina, L.; Malik, A. dan Najib, A. 2016. Uji Aktivitas Antiradikal Bebas Ekstrak Etanol Daun Kemangi (Ocimum basilicum L.) dengan Menggunakan Metode DPPH. Jurnal Fitofarmaka Indonesia, 3 (2) : 164-169.

66. FUez, Camila M.; SOuza, Raul O.; Fischer, P.; Leao, MFM; Duarte, JA.; Bollgon, AA.; Athayde, ML.; Zuravski, L; Oliveira, LFZ; and Machado, MM. 2017. Evaluation of basil extract (Ocimum basilicum L.) on oxidative, antigenotoxic and antiinflammatory effects in human leukocytes cell cultures exposed to challenging agents. Brazillian Journal of Pharmaceutical Sciences 53 (1) : 1-12.

67. Halle, Marie Patrice E.; Chipekam, Ndjifoum Moselle; Beyiha, Gerard; Fouda, Hermine; Coulibaly, Aminata; Hentchoya, Romuald; Kaze, Folefack Francois; Luma, Namme Henry and Ashuntantang, Gloria. 2018. Incidence, characteristics and prognosis of acute kidney injury in Cameroon: a prospective study at the Douala General Hospital. Renal Failure Journal 4 (1) : 30-37.

68. Hediget, MA., Johnson, RJ., Miyazaki, H., and Endou, H. 2004. Molecular Physiology of Urate Transport. Physiology Review 20 (4) : 125-133.

69. Hidayat dan Qomaruddin. 2015. Analisis Pengaruh Temperatur Pirolisis dan Bahan Biomassa Terhadap Kapasitas Pada Alat Pembuatan Asap Cair. Prossiding SNSST ke-6 : 29 - 35

70. Husein, A.T.T. dan Trihono. 1996. Buku ajar nefrologi anak. Ikatan Dokter Anak Indonesia. Jakarta.

71. Inuwa, HM, Aina, VO, Gabi, B., Aimola, I. And Ja'afaru, Lechman. 2011. Determination of Nephrotoxicity and Hepatoxicity of Monosodium Glutamate (MSG) Consumption. British Journal of Pharmacology and Toxicology 2 (3): 148-153.

72. Keown, PA. 2013. Predicting long-term outcome in renal transplantation. Kidney International 84 : 650-653.

73. Kumar, S. and Pandey, AK. 2013. Chemistry dan biological activities of flavonoid: an overview. The Scientific World Journal, 2013 : 1-16

74. Kusriningrum. 2008. Perancangan Percobaan. Airlannga University Press, Surabaya.

75. Liabeuf, S.; Lenglet, A.; Desjardins, L.; Neirynk, N.; Glorieux, G.; Lemke, HD.; Vanholder, R.; Diouf, M.; Choukroun, G.; and Massy, ZA. 2012. Plasma beta-2 microglobulin is associated with cardiovascular disease in uremic patients. Kidney International $82:$ 1297-1303.

76. Maiuolo, J., Oppedisano, F., Gratteri, S., Muscoli, C., and Mollace, V. 2016. Regulation of uric acid metabolism and excretion. International Journal of Cardiology $213: 8-14$.

77. Manurung, Maylisa Santauli; Trianto, Heru Fajar; Ilmiawan, M. In'am dan Handini, M. 2017. Pengaruh Pajanan Akut Formaldehid per Oral terhadap Gambaran Histologis Korteks Ginjal Tikus Putih Jantan Galur Wistar. Jurnal Cerebellum 3 (1) : 718-731.

78. Martinez, Sandra M.; Novoa, Jose M.; dan Hernandez, Francisco J. 2015. Pathophysiological role of different tubular epithelial cell death modes in acute kidney injury. Clinical Kidney Journal 8 (5) : 548-559.

79. Mehta, Shalini Kapoor dan Gowder, Sivakumar Joghi Thatha. 2015. Members of Antioxidant Machinery dan Their Functions. Basic Principles and Clinical Significance of Oxidative Stress, Chapter 4, London : INTECH, 29 page.

80. Ogbuagu O E, Nweke I N, Unekwe P C. 2015. Organ toxicity of monosodium glutamate in adult albino Wistar rats. J Med Investig Pract 6 (10) : 17.

81. Okwudiri, OO.; Aylvanus, AC.; and Peace, IA.. 2012. Monosodium Glutamate Induces Oxidative Stress and Affects Glucose Metabolism in the Kidney of Rats. International Journal of Biochemistry Research \& Review, 2(1): 1-11.

82. Rangkuti, R.H., Suwarso, E., dan Hasibuan, P.A.Z., 2013. Pengaruh Pemberian Monosodium Glutamat (MSG) Pada Pembentukan Mikronukleus Sel Darah Merah Mencit. Journal of Pharmaceutics and Pharmacology 3 (1), 29-36.

83. Ressang, A.A. 1984. Patologi khusus veteriner. IFAD Project. Denpasar.

84. S. Saha, M.K. Mukhopadhyay, P.D. Ghosh, and D. Nath. 2012. Effect of Methanolic Leaf Extract of Ocimum basilicum L. On Benzene-Induced Hematotoxicity in Mice. Evidendece-Based Complementary and Alternative Medicine 2 (3):17.

85. Sharma, A; Prasongwattana, V; Cha'on, U; Selmi, C; Hipkaeo, W; Boonnate, P; Pethlert, S; Titipungul, T; Intarawichian, P; Waraasawapati, S; Puapiroj, A; Sitprija, V and Reungjui, S. 2013. Monosodium glutamate (MSG) consumption is 
associated with urolithiasis dan urinary tract obstruction in rats. PLoS One 8 (9) : 1-9.

86. Sibernagl, S. 2003. Color Atlas of Physiology. New York : At a Glance.

87. Sparringa, RA. 2014. Pedoman Uji Toksisitas Nonklinik secara in vivo. BPOM, Jakarta. 165 halaman.

88. Thomas, ME; Blaine, C; Dawnay, A; Devonald, MAJ; Ftouh, S; Latchem, S; Lewington, A; Milford, DV and Ostermann, M. 2015. The definition of acute kidney injury and its use in practice. Kidney International; 87 (10) : 62-73.

89. Tawfilk, MS dan Badr, N. 2012. Adverse Effects of Monosodium Glutamate on Liver dan Kidney Functions in Adult Rats dan Potential Protective Effect of Vitamins C dan E. Food and Nutrition Sciences, 3(5) : 651-659.
90. Wahyudi, A., Yenni, B. dan Septianawati, P. 2018. Pengaruh Ekstrak Etanol Daun Kemangi (Ocimum basilicum L folium) Terhadap Kadar SGOT dan SGPT Tikus Putih (Rattus novergicus strain wistar) yang di induksi MSG. Herb Medicine Journal 1 (1) : 30-38.

91. Widiarti, W., Siswati, E., Setiyawati, A., Rohmah IM., dan Prastyo, E. 2013. Pengembangan Usaha Produksi Tikus Putih (Rattus norvegicus) Tersertifikasi Dalam Upaya Memenuhi Kebutuhan Hewan Laboratorium. Artikel DIKTI : 1-5. Available at http://artikel.dikti.go.id/index.php/PKMK/article/v iew/149.

92. Young, IS and Woodside, JV. 2001. Antioxidants in health and disease. J Clin Pathol juni 2001;54 :176-186. 